\title{
Does the capital market spur economic growth? Evidence from Nigeria
}

Taiwo Adewale Muritala,

Department of Accounting \& Finance, Fountain University Osogbo, Nigeria

Morufat Ogunji,

Department of Accounting \& Finance, Fountain University Osogbo, Nigeria

Keywords: the capital market; economic growth; the augmented Dickey Fuller test; OLS; Nigeria JEL: G3, G21, L25, C25, C33, O55

\begin{abstract}
This study critically examines the relationship between the capital market and economic growth of Nigeria. Data are mainly obtained from secondary sources, the CBN statistical bulletin over the period of 1980-2015. The results from the augmented Dickey Fuller unit root test show that all the variables were stationary at the level except RGDP, MCAP and TNI, which were stationary at the first difference. The results from Ordinary Least Square (OLS) reveal that total new issue, market capital-
\end{abstract}

ization, and total listing positively impact the economy while the value of the transaction has a negative impact on real gross domestic product. The study recommends, among others, that the government implement measures to build up investors' confidence in the capital market by fair transactions, by increasing investment instruments on the market; all the tiers of government should encourage funding their realistic development program through the capital market. 


\section{Introduction}

The capital market has been identified as an institution that contributes to the economic growth and development of emerging and developed economies. This is made possible through some of the vital roles played such as channelling resources, promoting reforms to modernize the financial sectors, as an institution with the financial intermediation capacity to link deficit to the surplus sector of the economy, and as a veritable tool in the mobilization and allocation of savings among competitive uses which are critical to the growth and efficiency of the economy [Donwa, Odia, 2010]. It helps channel capital or long-term resources to firms with relatively high and increasing productivity thus enhancing economic expansion and growth. Ekundayo [Ekundayo, 2002] argues that a nation requires a lot of local and foreign investments to attain sustainable economic growth and development. The capital market provides a means through which this is made possible. However, the paucity of long-term capital has posed the greatest predicament to economic development in most African countries, including Nigeria.

Osaze [Osaze, 2000] sees the capital market as the driver of any economy toward growth and development because it is essential for long-term growth capital formation. It is crucial in the mobilization of savings and channelling of such savings into profitable self-liquidating investment. The Nigerian capital market provides the necessary lubricant that keeps the wheel of the economy turning. Not only does it provide the funds required for investment but it also efficiently allocates these funds toward projects with the best returns to fund owners. This allocative function is critical in determining the overall growth of the economy. The functioning of the capital market affects liquidity, the acquisition of information about firms, risk diversification, savings mobilization, and corporate control. Therefore, by altering the quality of these services, the functioning of stock markets can alter the rate of economic growth. Okereke-Onyiuke [Okereke-Onyiuke, 2000] posits that a cheap source of funds from the capital market remains a critical element in the sustainable development of the economy. She enumerated the advantages of capital market financing to include no short repayment.

\section{Statement of the Problem}

There is abundant evidence that most Nigerian businesses lack long-term capital. The business sector has depended mainly on short-term financing such as overdrafts to finance even long-term capital. Market capitalization, new issues, and trading value on the nation's bourse (stock exchange) have a positive correlation with the economy of the country.

The latest literature has evidenced that the capital market has been instrumented to the initial twenty-five banks that met the minimum capital requirement during the banking sector consolidation in 2005 , yet there is still incommensurate influence on the macro-economic level. Hence, this study intends to provide answers concerning why there is under-performance in the capital market operations and focus on ways to enhance positive economic growth.

This study was undertaken in order to examine the contribution of the capital market to the Nigerian economic growth and development. Aside from the social and institutional factors inhibiting the process of economic development in Nigeria, the bottleneck created by the dearth of finances for the economy constitutes a major setback to its development. As a result, it is necessary to evaluate the Nigerian financial market.

\section{Justification of the Study}

The study explores the effectiveness of capital market instruments for Nigerian capital economic growth. Though the scope of the study was limited to the capital market, it is hoped that the exploration of this market will provide a broad view of the operations of the capital market. It will contribute to existing literature on the subject matter by empirically investigating the role that the capital market plays in the economic growth and development of the country. The main contribution of this study is that it will provide policy recommendations to policy-makers on ways to improve the operations and activities of the capital market.

\section{Review of Relevant Literature}

\section{Theoretical Framework}

The theoretical explanation on the nexus between the capital market and economic growth can be elaborated using the Efficient Market Hypothesis (EMH) developed by Fama in 1965. According to EMH, capital markets are efficient and prices of traded assets already reflect all known information and therefore are unbiased because they represent the collective beliefs of all investors about future prospects. The previous test of the EMH has relied on the long-range dependence of equity returns. It shows that past information has been found to be useful in improving predictive accuracy. This assertion tends to invalidate the EMH in most developing countries. Equity prices tend to exhibit long memory or long range dependence because of the narrowness of their market arising from immature regulatory and institutional arrangements. It has been noted that where the market is highly and unreasonably speculative, investors will be discouraged from parting with their funds for fear of incurring financial losses. The situations like the one mentioned above have a detrimental effect on the economic growth of any country, meaning investors will refuse to invest in financial assets. The implication is that companies cannot raise additional capital for expansion. Thus, it suffices to say that efficiency of the capital market is a necessary condition for growth in Nigeria [Nyong, 2003].

\section{Efficient Market Hypothesis}

Owolabi [Owolabi, Okwu, 2011] claimed that the capital market is characterized by the divisibility distributing 
wealth between shares and also by liquidity that is used to convert assets into cash, which may not be possible if the market is not efficient. Efficiency enables investors to rate a company for higher yield and also to be familiar with the economic situation.

Saeed et al. [Saeed et al., 2011] posits that the efficient market hypothesis is effective in the processing of information; the prices of securities observed at anytime are based upon a correct evaluation of all information. When firms issue securities that represent ownership of firm activities, they can do so under the assumption that they are paying fair prices. Where there is no useful information for predicting a future price change, the best option for tomorrow prices therefore becomes today's price, which is called the random weak hypothesis. Random weak hypothesis theory is used in stock price movements that are completely random and unpredictable.

Efficient adherence to the random weak hypothesis (RWH) eliminates the usefulness of information on past prices, which is called the weak form of the efficient market hypothesis, while a semi-strong form of the market is that an asset is worth what the market says it is worth and that the market quickly and correctly evaluates all public information related to the worth of assets, which are very useful to the investors. The strong form of the efficient capital market is that the market generally anticipates the release of useful information so that insiders cannot beat the market of information.

\section{Theories of the Capital Market}

\section{- $\quad$ Loanable Funds Theory (LFT)}

The theory of loanable funds is a term in economics used to describe money that is available to borrow. It is another word for financial assets, the market that brings borrowers and savers together. In particular, loanable funds consist of bank loans and household savings.

\section{- Exogenous Money}

Exogenous money is either money coming from abroad or money created by the international banking system operating within a country. Its usual form is that of interest bearing loans which are not necessarily directed at productive capacity and furthering the needs of society, and these are loans that hand control of society to the narrow elite.

\section{Conceptual Framework}

\section{Definition of the Capital Market}

The capital market is defined as the market where medium to long term financing can be raised. The capital market is the market for dealing (that is lending and borrowing) in long term loanable funds. The capital market offers a variety of financial instruments that enable economic agents to pool, price and exchange risk. Through assets with attractive yields, liquidity and risk characteristics, it encourages saving in the financial form. According to Al-Faki [Al-Faki, 2006], the capital market is a network of specialized financial institutions, a series of mechanisms, processes and infrastructure that, in various ways, facilitate bringing suppliers and users of medium to long term capital together for investment in an economic development project".

Jhingan [Jhingan, 2004] states that the capital market is the market that deals with long term loans. It supplies industries with fixed and working capital and finances medium and long term borrowing by central, state and local governments. Thus, the capital market comprises a complex of institutions and mechanisms through which medium and long term funds are pooled and made available to individual businesses and governments.

The capital market has been identified as an institution that contributes to the socioeconomic growth and development of emerging and developed economies. This is made possible through some vital roles played, such as channeling resources, promoting reforms to modernize the financial sectors, financial intermediation capacity to link deficit to the surplus sector of the economy, and a veritable tool in the mobilization and allocation of savings toward competitive uses, which are critical to the growth and efficiency of the economy.

\section{Overview of the Nigerian Capital Market}

The capital market is a cornerstone of every financial system since it provides the funds needed for financing not only business and other economic institutions, but also the government's programs in general. The capital market is essentially a market for long term securities, which are stock, debenture and bonds lasting for usually longer than three years. The proper functioning of the capital market was not set up until the establishment of the Central Bank in 1959 and launching of the Lagos stock exchange in 1961 even though securities were floated as far back as 1946.

The need to have an organized stock exchange came up and a committee was set up by the government under the chairmanship of Prof. R.W. Barbock to consider the feasibility of having an indigenous forum for the purchase and sale of shares and stocks. The Nigerian capital market was established for the following reasons below:

1. To overcome difficulties of selling government stock

2. To provide local opportunities and long term lending

3. To enable the authorities to mobilize long term capital for economic growth and development

4. To provide foreign businesses with the chance of offering their shares to interested Nigerians, so that they are able to invest and participate in the ownership of these foreign businesses.

In view of the above, the major participants in the capital market are: the government, quoted (listed) companies, stock brokers, the Central Bank of Nigeria (C.B.N), banking and non-banking financial institutions, the Nigerian Stock Exchange, and the Nigerian Securities and Exchange Commission. 


\section{The Nigerian Stock Exchange}

As one of the components of the capital market, the exchange is a private, non-profit organization, limited by guarantees. It was incorporated through the inspiration and support of businessmen and the federal government. However the exchange is owned by about 300 members, This group includes financial institutions, stockbrokers and individual, prominent Nigerians, who have contributed to the development of the stock market and the Nigerian economy. The stock exchange is thus an institution of the capital market which provides trading floors where all dealing members operate on every business day. The exchange now has nine (9) branches and all the branches function principally as a trading floor.

\section{Economic Growth}

Economic growth means an increase in the capacity of an economy to produce goods and services, compared with one period of time to another. Economic growth is a process by which a nation's wealth increases over time. The most widely used measures of economic growth are the rate of growth in a country's total output of goods and services gauged by the gross domestic product (GDP). Economic growth can also be referred to as the increase of per capital gross domestic product (GDP) or other measures of aggregate income, typically reported as the annual rate of change in real GDP. Economic growth is primarily driven by the improvement in productivity, which involves producing more goods and services with the same inputs of labor, capital, energy, and materials.

\section{Impact of Capital Market on Economic Growth in Nigeria}

The Nigerian capital market provides the necessary lubricant to keep turning the wheel of the economy. Not only does it provide the funds required for investment but it also efficiently allocates these funds to projects of best returns to fund owners. The market is vital to the growth and development of any country because it supports government and corporate initiatives which finance the exploitation of new ideas and facilitate the management of financial risk.

\section{Empirical Review on the Capital Market and Economic Growth}

Several attempts have been made by previous writers to link the growth of the capital market with the economy. Agarwal [Agarwal, 2001] argued that the development of the financial sector facilitates the capital market's development and in turn raises the real growth of the economy. Moreover, Pedro and Erwan [Erwan, Pedro, 2004] asserted that the financial market's development raises output by increasing the capital used in production and by ensuring that capital is put to its best uses. Ezeoha, Ebele and NdiOkereke [Ezeoha et al., 2009] investigated the nature of the relationship that exists between the stock market's development and the level of investment (domestic private investment and foreign private investment) flows in Nigeria. The study used pooled cross-country time-series regression of forty-one countries from 1976 to 1993 to evaluate this association. The study toed the line. The growth rate of Gross Domestic Product (GDP) per capita was regressed on a variety of variables designed to control for initial conditions, political stability, investment in human capital, and macroeconomic conditions; and then it included the conglomerated index of stock market development. The finding was that a strong correlation between overall stock market development and long-run economic growth exists. This means that the result is consistent with the theories that imply a positive relationship between stock market development and economic growth.

\section{Empirical Evidence from Other Countries}

Demetriades, Arestis and Luintel [Demetriades et. al., 2001] utilized time series data from five developed countries to examine the relationship between the stock market and economic growth, controlling for other effects of the banking system and stock market volatility. Their results support the view that, although banks and the stock market may promote economic growth, the effect of banks is larger. They suggested that the contribution of the stock market to economic growth may have been exaggerated by studies that use cross country regressions. Mohtadi and Agarwal [Mohtadi, Agarwal, 2004] examined the capital market and economic growth in developing countries using a panel data approach that covers 21 emerging markets over 21 years (1977-1997) and found that turnover ratio is an important and statistically significant determinant of investment by firms and that this investment in turn is a significant determinant of aggregate growth. Foreign direct investment is also found to have a strong positive influence on aggregate growth. The result of their study indicates that both turnover ratio and market capitalization are important variables as determinants of economic growth.

Mishra et al. [Mishra et al., 2010] examined the impact of capital market efficiency on the economic growth of India using time series data on market capitalization, total market turnover and stock price index over the period spanning from the first quarter of 1991 to the first quarter of 2010. Their study reveals that there is a linkage between capital market efficiency and economic growth in India. This linkage is established through a high rate of market capitalization and total market turnover. The large size of the capital market as measured by greater market capitalization is positively correlated with the ability to mobilize capital and diversify risk on an economy-wide basis. The increasing trend of market capitalization in India would certainly bring capital market efficiency and thereby contribute to the economic growth of the country. 


\section{Empirical Evidence from Nigeria}

Osinubi and Amaghionyeodiwe [Osinubi, Amaghionyeodiwe, 2003] also examined the relationship between the Nigerian stock market and economic growth during the period 1980-2000 using ordinary least squares regression (OLS). The result indicated that there is a positive relationship between the stock market and economic growth and suggested the pursuit of policies geared towards the rapid development of the stock market.

Pedro and Erwan [Erwan, Pedro, 2004] assert that financial market development leads to economic growth and Abdullahi [Abdullahi, 2005] also agrees with the assertion that capital market development in Nigeria is the engine of its economic growth. Moreover, Agarwal [Agarwal, 2001] argues that the financial sector's development facilitates the capital market's development and in turn increases the real growth of the economy. In the same vein, Kolapo and Adaramola [Kolapo, Adaramola, 2012] find that the Nigerian capital market's development has a significant relationship with economic growth. Obamiro [Obamiro, 2005], cited in Kolapo and Adaramola [Kolapo, Adaramola 2012], investigated the role of the Nigerian stock market in light of economic growth. The author reported a significant positive effect of the stock market on economic growth. He suggested that the government should create a more enabling environment so as to increase the efficiency of the stock market in order to attain higher economic growth.

Ewah, Esang and Bassey [Ewah et al., 2009] appraised the impact of Nigerian capital market efficiency on the economic growth of the nation using time series data from 1961 to 2004. They found that the capital market in Nigeria has the potential for inducing growth but it has not contributed meaningfully to the economic growth of the country because of low market capitalization, illiquidity, misappropriation of funds among others. Ezeoha, Ebele and NdiOkereke [Ezeoha et al., 2009] investigated the nature of the relationship that exists between the stock market's development and the level of investment (domestic private investment and foreign private investment) flows in Nigeria. The study discovered that the stock market's development promotes domestic private investment flows, thus suggesting the enhancement of the economy's production capacity as well as the promotion of the growth of national output.

In Nigeria, some authors have also attempted to examine the relationship between the stock market's development and economic growth. For instance, Adam and Sanni [Adam, Sanni, 2005] examined the role of the stock market in Nigeria's economic growth using Granger-causality test and regression analysis. The authors discovered a one-way causality between GDP growth and market capitalization and a two-way causality between GDP growth and market turnover. They also observed a positive and significant relationship between GDP growth turnover ratios. The authors advised that the government should encourage the development of the capital market since it has a positive effect on economic growth.
Abu [Abu, 2009] examined whether the stock market's development raises economic growth in Nigeria, by employing the error correction approach. The econometric results indicate that stock market development (market capitalization GDP ratio) increases economic growth. He, however, recommended the removal of impediments to stock market development, which include tax, legal and regulatory barriers, the development of the nation's infrastructure to create an enabling environment where business can thrive, employment policies that will increase the productivity and efficiency of firms as well as encourage the Nigerian Securities and Exchange Commission to facilitate the growth of the market, restoring the confidence of the stock market's participants and safeguarding the interests of shareholders by checking sharp practices of market operators.

The capital market can affect economic development through the mobilization of long-term resources, the provision of liquidity, risk diversification, privatization, securitization or risk transfers and the determination of the cost of capital for project valuation [Chiwuba, Amos, 2011]. Ariyo and Adelegan [Ariyo, Adelegan, 2005] contend that the liberalization of the capital market contributes to the growth of the Nigerian capital market, yet its impact on the macro-economy is quite negligible. Ekundayo [Ekundayo, 2002] argues that a nation requires a lot of local and foreign investments to attain sustainable economic growth and development. The capital market provides a means through which this is made possible. Ewah, Esang and Bassey [Ewah et al., 2009] revealed that the capital market provides opportunities for the purchase and sale of existing securities among investors thereby encouraging the populace to invest in securities fostering economic growth.

In Nigeria, experience has shown that the revenue generated from taxation and statutory allocation is not enough to finance recurrent and capital expenditure of most state governments of the federation. Therefore, it is necessary for the government to look for another avenue to source funds such as the capital market for capital inflow to bridge their growth gaps. For economic growth and the development of any economy, the existence of a good financial system is needed.

According to Dabwor [Dabwor, 2009] the capital market is a complex of institutional arrangements that facilitates the intermediation of funds in an economy. The financial system is a complex of institutions and mechanisms whereby medium and long term funds are pooled and made available to businesses, the government and individuals; thereby instruments already outstanding are transferred. Saeed et al. [Saeed et al., 2011] extended the thesis through inter-country analysis observing that monetary intermediaries such as savings and loan institutions, investment trusts, pension funds and security markets tend to grow as the country especially depends on economic development and structural change from its growth and, while the scope of the communal system is declining, he used his observation in the various 
segments of the finance system to develop the 'planed approach' while emphasizing the development of non-market sources of financing such as the security market.

In his study he discovered that the banking system contributed $80-90 \%$ to the growth of the economy about two decades ago. The significance of the open market for primary security in developing countries is not usual as it is a mere reflection of the low level of development and, in turn, per capital income. Thus, the investment saving mechanism is still rudimentary in those countries affected by growth. Studies have shown that in the absence of an open market for primary securities, the role of monetary system is intermediate and very crucial. Thus, in many developing countries the banking system is depended upon to promote investment through the issue of currency, demand deposits (DD) and time deposits (TD), which can be extended as credit to private and public investors.

Beckaert, Harvey and Lundblad [Bekaert et al., 2005] analyzed financial liberalization as a special case of the capital market's development and determined that equity market liberalization, on average, led to a $1 \%$ increase in annual real economic growth. According to Esosa [Esosa, 2007], the Securities and Exchange Commission (SEC) is the apex regulatory/supervisory authority on the capital market. It was established in 1979 by the Securities and Exchange Commission Decree, which was reenacted in 1988 as Securities and Exchange Commission Decree No. 29 of 1988 for the purpose of protecting investors as well developing the capital market.

\section{Data Collection Method and Analysis}

The data for this study was obtained mainly from secondary sources, particularly, from the Central Bank of Nigeria (CBN), statistical bulletins, the Nigerian Stock Exchange (NSE), fact books, the Security and Exchange Commission (SEC), market bulletins and relevant journals. The procedure for analyzing the data was the multiple regression analysis to test whether the capital market indices have impacted the economic growth of Nigeria proxy by Real Gross Domestic Product (RGDP). Thus, the economic growth was proxied using the constant value of Real Gross Domestic Product (RGDP) while the capital market performance variables were proxied using the Market Capitalization (MCAP), Total New Issues (TNI), Total Listed Equity and Government Stock (TLS) and Value of Transactions (VLT). Since most of the time series data are non-stationary, we decided to carry out an augmented Dickey Fuller (ADF) unit root tests for stationarity.

\section{Model Specification}

The model which specifies that the economic growth proxy by Real Gross Domestic Product (RGDP) is significantly influenced by the capital market indices (market capitalization, new issues, value of transaction and total listing) is formulated as follows:

$\mathrm{GDP}=\mathrm{f}(\mathrm{MCAP}, \mathrm{TNI}, \mathrm{VLT}, \mathrm{TLS})$

$\operatorname{LnGDP}=\beta_{0}+\beta_{1} \operatorname{LnMCAP}+\beta_{2} \operatorname{LnTNI}+\beta_{3} \operatorname{LnVLT}+\beta_{4}$ LnTLS + U

Where;

The a priori expectation is $\beta_{1}, \beta_{2}, \beta_{3}, \beta_{4}>0$

LnGDP $=$ Gross Domestic Product

LnMCAP $=$ Market Capitalization

LnTNI $=$ Total New Issues

LnVLT $=$ Value of Transaction

LnTLS= Total Listed Equity and Government Stock

$\mathrm{U}=$ Disturbance Term

$\beta_{0}=$ Intercept

$\beta_{1}-\beta_{4}$ Coefficient of the Independent Variables It should be noted that all variables are given in their natural logarithm form.

\section{Presentation and Interpretation of Results}

\section{Descriptive Statistics}

The descriptive statistics of all the variables used in the study are shown below. As can be observed from the table, TLS has the lowest mean value of 255.6250 and the mean value of MCAP has the highest mean value of 1831675, whereas the mean values of RGDP and TNI are 366797.0 and 355442.2 respectively. The analysis was also fortified by the value of skewness and kurtosis of the entire variable involved in the models. The skewness is the measure of the symmetry of the histogram while the kurtosis is the measure of the tail shape of the histogram. Hence all the values are positive with the exception of TLS. The benchmark for symmetric distribution, i.e., for the skewness, is how close the variable is to zero while the case of the kurtosis is three (mesokurtic) but values lower than that are called platykurtic. All the variables are leptokurtic with the exception of TLS, which is platykurtic in nature. 
Table 4.1

Descriptive Statistic Data

\begin{tabular}{|c|c|c|c|c|}
\hline & REAL GDP & MCAP & TLS & TNI \\
\hline Mean & 366797.0 & 1831675. & 255.6250 & 355442.2 \\
\hline Median & 287576.4 & 221411.2 & 264.0000 & 7911.350 \\
\hline Minimum & 901300.0 & 13294059 & 310.0000 & 2440000 . \\
\hline Maximum & 31546.80 & 4025.700 & 157.0000 & 159.8000 \\
\hline Std. Dev & 206093.0 & 3627334. & 32.91803 & 715778.5 \\
\hline Skewness & 1.002104 & 2.074112 & -0.998310 & 1.864197 \\
\hline Kurtosis & 3.156120 & 5.872377 & 4.078518 & 4.898315 \\
\hline Probability & 0.067600 & 0.000000 & 0.032286 & 0.000009 \\
\hline
\end{tabular}

Source: Researcher's Computation (2015)

\section{Unit Root Result}

From the table below, the results of the unit root test show that RGDP, TNI, and VLT are stationary at their first difference, i.e. other 1(1) while MCAP and TLS are stationary at their level, i.e. other 1(0).

Table 4.2

Augmented Dickey Fuller Unit Root Test

\begin{tabular}{|c|c|c|}
\hline VARIABLES & ADF & ORDER OF INTEGRATION \\
\hline RGDP & $-5.5244(0.0001)$ & $1(1)$ \\
\hline MCAP & $-3.1924(0.0316)$ & $1(1)$ \\
\hline TLS & $-3.5196(0,0141)$ & $1(0)$ \\
\hline TNI & $-3.1658(0.0349)$ & $1(1)$ \\
\hline VLS & $-4.7342(0.0010)$ & $1(0)$ \\
\hline
\end{tabular}

Source: Researcher's Computation (2015)

\section{Discussion of the Regression Result}

The analysis of impact of the capital market on the economic situation in Nigeria is presented in the table above. The results obtained from the model indicate that the co-efficient of determination $\left(\mathrm{R}^{2}\right)$ has a goodness of fit with $86.34 \%$ of the economic growth rate. The reason for being a goodness of fit is because it is statistically above the bench mark of $50 \%$. The Durbin-Watson statistic of 1.08 is also below the benchmark of 2, from which we can conclude that there is no auto-correlation in the model specification. It can be seen that TNI and TLS conform to a prior expectations except MCAP, whose a priori expectation should have a positive relationship but has a negative relationship.. VLS, whose a priori expectation should have a negative relationship, has a positive relationship. MCAP would lead to a 4.02 unit decrease change in RGDP, which is not statistically significant. A unit change in TLS would lead to a 2120.02 unit increase in RGDP, which is statistically significant at a $1 \%$ level. The unit change in TNI would cause a 21 unit increase in RGDP, which is statistically significant at $1 \%$. A unit change in VLS would lead to $1.5 \%$ increase in RGDP, which is not significant. In terms of the t-statistic all explanatory variables are not significant except MCAP and TNI at a 1\% level. The tabulated F- statistic is 42.69 because the calculated value is greater than the tabulated value. 
Table 4.3

Ordinary Least Square Estimate (Static Model)

Dependent Variable: (RGDP)

Method: Least Squares

\begin{tabular}{|c|c|c|c|c|}
\hline Variable & Coefficient & Std. Error & t-Statistic & Prob. \\
\hline MC & -0.004028 & 0.008596 & -0.468576 & 0.6431 \\
\hline TLS & 2120.029 & 521.3650 & 4.066306 & 0.0004 \\
\hline TNI & 0.210739 & 0.047234 & 4.461570 & 0.0001 \\
\hline VLS & 0.001573 & 0.001238 & 1.270535 & 0.2147 \\
\hline C & -249937.5 & 130120.1 & -1.920822 & 0.0654 \\
\hline R-squared & 0.863490 & & & \\
\hline Adjusted R-squared & 0.843266 & & & \\
\hline F-statistic & 42.69677 & & & \\
\hline Prob f-stat & $(0.000000)$ & & & \\
\hline Durbin-Watson stat & 1.084681 & & & \\
\hline
\end{tabular}

Source: Researcher's Computation (2015)

\section{Summary of Findings}

The study examines the impact of the capital market on the economic growth of Nigeria from 1980 to 2011. The findings of the study reveal the following:

- The regression result confirms that a positive relationship exists between the capital market and economic growth. The relationship is statistically significant. This means that the impact of the capital market on economic growth is strong and significant.

- Another major outcome of the study is that a unit increase in total listing of equity and government stock (TLS) results in an increase in GDP. The implication of this is that the economy responds favorably to measures taken to increase TLS on the Nigerian Stock Exchange.

- The positive result of the total listing of equity and government stock implies that funds raised by the industries and governments on the capital market are spent on a productive sector, which enhances economic growth.

- The result of the value of transaction in the capital market means that the simplicity in buying and selling securities has the potential to influence economic growth positively.

These findings agree with Ewah, Esang and Bassey [Ewah et al., 2009], who found that the capital market in Nigeria has the potential for inducing growth but has not contributed meaningfully to the economic growth of Nigeria due to low market capitalization.

\section{Conclusion}

The study reveals the capital market's impacts on economic growth via market capitalization, value of transaction, and total listing of equity and government stock. As it was observed, market capitalization, government stock and value of transaction are important capital market variables that are capable of influencing economic growth. Hence the capital market remains one of the key institutions in every economy that has the power to influence economic growth. Therefore the organized private sector should invest in it. The market capitalization has not significantly impacted GDP while the volume of transaction and total listed equities and government stock have a significant impact on GDP. The government is therefore advised to put up measures to stem up investors' confidence and activities on the market and more foreign investors should be encouraged to participate on the market to encourage improvement in the declining market capitalization so that it could contribute significantly to Nigerian economic growth.

\section{Policy Recommendations}

In order for the Nigerian capital market to be a pivotal force in Nigerian economic growth and development, this study recommends that there should be an improvement in the declining market capitalization by encouraging more foreign investors to participate on the market. Also, there is also the need to restore confidence in the market of regulatory authorities by ensuring transparency and fair trading transactions and dealing on the stock 
exchange. Moreover, there is a need for an increase in the total member of listed companies to ensure a stable macroeconomic environment in order to encourage foreign multinational companies (MNCs) or their subsidiaries to be listed on the Nigerian Stock Exchange. Lastly, to boost the value of transactions on the Nigerian capital market, there is a need for the availability of more investment instruments such as derivatives, convertibles, futures, and swap options on the market. However, given the present political dispensation, all the tiers of government should be encouraged to fund their realistic development programs through the capital market. This will serve as an avenue to free resources that may be used in other spheres of the economy.

\section{References}

Abdulahi S.A. (2005) Capital market performance and economic development in Nigeria. An empirical analysis paper presented at the Dept. of Business Administration. Bayero University Kano.

Abu N. (2009) Does stock market development raise economic growth? Evidence from Nigeria. Journal of Banking and Finance, vol. 1, no. 1, pp. 15-26.

Adam J.A., Sanni I. (2005) Stock Market Development and Nigeriahat may be uGrowth. Journal of Economics and Allied Fields, vol. 2. no. 2, pp. 116-132.

Agarwal S. (2001) Stock market development and economic growth: Preliminary evidence from African countries. Retrieved, May, 20, 2013.

Al-Faki M. (2006) The Nigerian capital market and socio-economic development. A paper presented at the 4th distinguished Faculty of Social Science, Public Lectures, University of Benin, 9-16.

Amaral P., Quintin E. (2006) A competitive model of the informal sector. Journal of Monetary Economics, vol. 53, pp. 1541-1553.

Amaral P.S., Quintin E. (2004) The implications of capital-skill complementarily in economies with large informal sectors. Center for Latin America Working Papers, 0404, Federal Reserve Bank of Dallas.

Ariyo A., Adelegan O. (2005) Assessing the impact of capital market reforms in Nigeria. An incremental approach. Paper presented at $46^{\text {th }}$ annual conference of the Nigeria Economic Society in Lagos in August 2005.

Bekaert G., Harvey C., Lundlad C. (2005) Does financial liberation spur growth? Journal of Financial Economics, vol. 77, no. 1, pp. 3-55.

Ben Naccur S., Ghazouani S. (2007) Stock markets, banks, and economic growth: Empirical evidence from MENA region. Research in International Business Finance, vol. 21, no. 2, pp. 297-315.
Central Bank of Nigeria (CBN) (2012) Statistical Bulletins of 2012. Abuja, Central Bank of Nigeria publication.

Chinwuba O., Amos O.A (2011) Stimulating economic development through the capital market: The Nigerian experience. Available at: www.transcampus.org (accessed: 20.08.2012).

Dabwor T.D. (2009) The Nigerian banking system and the challenges of financial intermediation in the $21^{\text {th }}$ century. Jos Journal of Economics, vol. 4, no. 1.

Demetriades P., Arestis P., Luintel K. (2001) Financial development and economic growth: The role of stock markets. Journal of Money, Credit, and Banking, vol. 33, pp. 16-41.

Donwa P. Odia J. (2010) An empirical analysis of the impact of the Nigerian capital market on her socio-economic development. Journal of Social Science, vol. 24, no. 2, p. 135.

Ekundayo I.K. (2002) Creating conducive environment for investment in Nigerian capital market. Paper presented at public enlightenment on opportunities in the capital market for industrial development of Kogi State.

Erwan Q., Pedro Amaral (2004) Financial intermediation and TFP differences. Meeting papers 377, Society for Economic Dynamics.

Esosa B.O. (2007) Capital market, Africa, and global. London, The book house company.

Ewah S.O.E., Esang A.E., Bassey J.U. (2009) Appraisal of capital market efficiency on economic growth in Nigeria. International Journal of Business and Management, vol. 4, no. 12, pp. 219-225.

Ezeoha A., Ebele O., NdiOkereke O. (2009) Stock market development and private investment growth in Nigeria. Journal of Sustainable Development in Africa, vol. 11, no. 2 ,

Jhingan M.L. (2004) The Economic of Development and Planning. New Delhi, Vrinda Publications Limited.

Kolapo F.T., Adaramola A.O (2012) The impact of Nigerian capital on economic growth. International Journal of Developing Studies, vol. 1, no. 1, pp. 11-19.

Mbat D.O. (2001) Financial management. Domes Associates Publishers. Uyo, Nigeria First Edition.

Mishra P.K., Mishra U.S., Mishra B.R., Mishra P. (2010) Capital market efficiency and economic growth: The case of India. European Journal of Economics, Finance, and Administrative Sciences, vol. 27, no. 18, pp. 130-138.

Mohtadi H., Agarwal S. (2004) Financial markets and the financing choice of firms; Evidence from developing countries. Global Financial Journal, vol. 15, no. 2, pp. $52-70$. 
Nyong M.O. (2003) Predictability and volatility of stock return in three emerging markets: Nigeria, South Africa, and Brazil. Nigeria Journal of Economics and Development Matters, vol. 2, no. 1, pp. 12-29.

Obamiro J.K. (2005) Nigeria economy: Growth and the role of stock market. Journal of Economic and Financial studies, vol. 2, no. 2 .

Okereke-Onyiuke N. (2000) Stock market financing options for public projects in Nigeria NSE factbook 2000.

Osaze B.E. (2000) The Nigerian capital market in the African and global financial system. Benin City, Bofic Consulting Group Ltd.

Osinubi T.S., Amaghionyeodiwe L.A. (2003) Stock market development and long-run growth in Nigeria. Journal of African Business, vol. 4, no. 3, pp. 103-129.

Owolabi S.A., Okwu A.T. (2011) Empirical evaluation of contribution of value added tax to development of lagos state economy. Euro Journals Publishing, Inc Paper $97 / 137 / 139$.

Saeed S.K., Sargana Sh.M., Ayub U. (2011) Are equity markets efficient? Evidence from emerging economy. Interdisciplinary Journal of Contemporary Research in Business, vol. 3, no. 1, pp. 417-428. 